\title{
IMPLEMENTASI PROGRAM ADIWIYATA MELALUI PEMBELAJARAN LINGKUNGAN HIDUP DI SEKOLAH DASAR AL MUSLIM WADUNG ASRI WARU SIDOARJO
}

\author{
Budi Purwantiningsih ${ }^{(1)}$ \\ Asnal Mala ${ }^{(2)}$ \\ ${ }^{1,2}$ Fakultas Agama Islam, Universitas Sunan Giri Surabaya \\ (email : budipurwanti1912@gmail.com)
}

\begin{abstract}
The Adiwiyata is a program of the Minister of the Environment (KLH) with the Minister of National Education (Depdiknas) which aims to strive for how a love of the environment can be used as an educational content for students from an early age in formal education. One of the schools that has implemented the Adiwiyata program through its learning is the Al Muslim Waru Sidoarjo School. The objectives of this study include: Knowing the application of environmental learning through the Adiwiyata Program. (2) Knowing the Al Muslim elementary school curriculum. (3) Knowing the inhibiting factors in the implementation of environmental learning through the Adiwiyata Program. This study uses a qualitative method. The research location was at Al Muslim Elementary School, Jl.Raya Wadung Asri 39F, Waru District, Sidoarjo Regency. Data collection tools used in this study were interviews, documentation, and observation. The technique used is source triangulation starting from data collection, data reduction, data presentation and drawing conclusions. The results showed that 1) The application of environmental learning through the Adiwiyata Program was carried out with a school culture transformation strategy and habituation through three activities namely routine, programmed, and spontaneous activities carried out by the Al Muslim Elementary School in collaboration with outside parties. 2) The curriculum used is the Superior Curriculum, Green Environment which is a monolithic and integrated, both in theory and practice. 3) The obstacle faced in the implementation of environmental learning is the existence of new educators, the time allotted, green land which is still minimal when compared to the ratio of students of Al Muslim Waru Sidoarjo Elementary School.
\end{abstract}

\section{Keywords: Implementation, Adiwiyata, Green Environment}

\section{ABSTRAK}

Program Adiwiyata merupakan program Menteri Lingkungan Hidup (KLH) dengan Menteri Pendidikan Nasional (Depdiknas) yang bertujuan ntuk mengupayakan bagaimana kecintaan terhadap lingkungan yang dapat dijadikan sebagai muatan pendidikan bagi peserta didik sejak usia dini pada pendidikan formal. Salah satu Sekolah yang sudah mengimplementasikan program Adiwiyata melalui pembelajarannya adalah Sekolah Al Muslim Waru Sidoarjo. Adapun tujuan penelitian ini meliputi: Mengetahui penerapan pembelajaran lingkungan hidup melalui Program Adiwiyata. (2) Mengetahui kurikulum SD Al Muslim. (3) Mengetahui faktor penghambat dalam pelaksanaan pembelajaran lingkungan hidup melalui Program Adiwiyata. Penelitian ini menggunakan metode kualitatif. Lokasi penelitian di SD Al Muslim Jl.Raya Wadung Asri 39F, Kecamatan Waru Kabupaten Sidoarjo. Alat pengumpulan data yang Vol. 미. No. Q2. Iktober 2019 


\section{Budi Purwantiningsib}

Asnal Mala

digunakan dalam penelitian ini adalah wawancara, dokumentasi, dan observasi. Teknik yang digunakan adalah triangulasi sumber dimulai dari pengumpulan data, reduksi data, penyajian data dan penarikan kesimpulan. Hasil penelitian menunjukan bahwa 1) Penerapan pembelajaran lingkungan hidup melalui Program Adiwiyata dilaksanakan dengan strategi tranformasi budaya sekolah dan pembiasaan melalui tiga kegiatan yaitu kegiatan rutin, terprogram, dan kegiatan spontan yang dilaksanakan oleh Pihak SD Al Muslim yang bekerjasama dengan pihak luar sekolah. 2) Kurikulum yang digunakan adalah Kurikulum Unggulan yaitu Green Environment yang bersifat monolitik dan terintegrasi, baik secara teori maupun praktik. 3) Hambatan yang dihadapai dalam pelaksanaan pembelajaran lingkungan hidup ini adalah adanya tenaga pendidik baru, waktu yang diberikan, lahan hijau yang masih minim bila dibandingkan dengan rasio murid SD Al Muslim Waru Sidoarjo.

\section{Kata Kunci: Implementasi, Adiwiyata, Green Environment.}

\section{PENDAHULUAN}

Lahirnya era globalisasi ditandai dengan munculnya perkembangan ilmu pengetahuan dan teknologi yang menitikberatkan pada aspek teknologi informasi komunikasi, jasa dan transportasi. Perkembangan ilmu pengetahuan dan teknologi telah memaju lahirnya masyarakat industri, masyarakat yang dipenuhi dengan otomatisisasi, mekanisasi dan standarisasi. Dampak negatifnya, tentu terdapat limbah yang dikeluarkan industri atau pabrik yang mengandung bahan berbahaya atau beracun. Berbagai kalangan pemerhati lingkungan hidup telah berupaya mencari solusi alternatif terhadap permasalahan yang ditimbulkan limbah industri sebagai problem lingkungan hidup karena dapat menganggu keseimbangan ekosistem, merusak lingkungan hidup, dan menimbulkan pencemaran lingkungan.

Selain itu kebiasaan masyarakat yang tidak ramah lingkungan dan biasa dilakukan dalam kehidupan sehari-hari misalnya: membuang sampah sembarangan, acuh terhadap tumbuhan sekitar, mengeksploitasi tumbuhan/pohon secara besar-besaran, membuang limbah rumah tangga dan industri di sungai tanpa ada perlakuan terlebih dahulu, eksploitasi ikan secara besarbesaran dengan menggunakan bahan peledak yang justru dapat merusak habitat ikan itu sendiri, danmasih banyak lagi. Kegiatan-kegiatan semacam itu jika tidak dirubah akan menyebabkan kerusakan lingkungan secara global. Oleh karena itu untuk meningkatkan kesadaran akan cinta lingkungan hendaknya menjadi sebuah karakter yang harus dimiliki sejak dini.

Untuk membangkitkan kesadaran manusia terhadap lingkungan hidup di sekitarnya, proses yang paling penting dan harus dilakukan adalah dengan menyentuh hati. Jika proses penyadaran telah terjadi dan perubahan sikap dan pola pikir terhadap lingkungan telah terjadi, 
maka dapat dilakukan peningkatan pengetahuan dan pemahaman mengenai lingkungan hidup, serta peningkatan keterampilan dalam mengelola lingkungan hidup. Pada tahun 1986, pendidikan lingkungan hidup dan kependudukan dimasukkan ke dalam pendidikan formal dengan dibentuknya mata pelajaran. Dan sejak tahun 1989/1990 hingga saat ini berbagai pelatihan tentang lingkungan hidup telah diperkenalkan oleh Departemen Pendidikan Nasional bagi guru-guru SD, SMP dan SMA termasuk Sekolah Kejuruan (Anonim, 2009: 4).

Sekolah Dasar (SD) Al Muslim merupakan sekolah full day yang terletak di Jl.Raya Wadung Asri 39F, Kecamatan Waru Kabupaten Sidoarjo. Sekolah Dasar Al Muslim ini dirintis pada tahun 2006 dengan tujuan mencetak pemimpin profesional yang berkualitas dengan dibekali dengan imtaq dan iptek. Adapun pelaksanaan kegiatan belajar mengajar dimulai pukul 07.15-15.45 WIB mulai hari Senin-Jumat. Khusus untuk Sabtu dimulai pukul 07.30-10.00 WIB yang diisi dengan kegiatan ekstrakurikuler dan kegiatan remidial.

Adapun Kurikulum SD Al Muslim pada umunya menggunakan Kurikulum Tingkat Satuan Pendidikan (KTSP) dan Kurikulum 2013 yang bertujuan untuk membentuk karakter siswa. Namun yang menarik adalah Sekolah Dasar Al Muslim ini memiliki kurikulum khas spesifik tersendiri yang berbeda dengan kebanyakan Sekolah pada umumnya yaitu Full Day School \& Leadership. Sehingga Kurikulum SD Al Muslim ini tidak seluruhnya ditentukan Departemen Pendidikan seperti yang berlaku saat ini, tetapi dimodifikasi melalui substitusi integral dengan agama yang dimasukkan dalam mata pelajaran Unggulan yaitu: Mata Pelajaran Leadership dan Green Education. Mata Pelajaran unggulan ini berisi aspek-aspek yang diharapkan menjadi suatu kebiasaan (habid) dan sangat berguna di dalam kehidupan peserta didiknya. Kedua kurikulum terintegrasi sebagai subyek dari semua mata pelajaran, selain itu mata pelajaran keduannya juga diberikan sebagai mata pelajaran tersendiri (monolitik) yang diberikan kepada siswa.

Pembelajaran Lingkungan hidup yang diberikan kepada siswa SD Al Muslim ini merupakan bagian dari program Adiwiyata yang telah disahkan oleh Kementerian Negara Lingkungan Hidup (KLH) dengan Menteri Pendidikan Nasional (Depdiknas) tahun 1996 yang kemudian direvisi pada bulan Juni 2005. Penandatanganan MOU tersebut bermakna sebagai usaha untuk mengupayakan bagaimana kecintaan terhadap lingkungan sehingga dapat dijadikan sebagai muatan pendidikan bagi peserta didik sejak usia dini pada pendidikan formal. Karena segala yang tersusun atau terstruktur sejak awal, diharapkan dapat memberikan hasil atau pencapaian yang lebih baik dalam pengelolaan lingkungan hidup. 


\section{Budi Purwantiningsih}

Asnal Mala

Program Adiwiyata bertujuan untuk menciptakan kondisi yang baik bagi sekolah untuk menjadi tempat pembelajaran dan penyadaran warga sekolah yang diwujudkan dalam bentuk: (1) Pengembangan kebijakan sekolah peduli dan berbudaya lingkungan, (2) Pengembangan kurikulum berbasis lingkungan, (3) Pengembangan kegiatan lingkungan berbasis partisipatif, dan (4) Pengembangan dan pengelolaan sarana pendukung sekolah berbudaya lingkungan seperti: hemat energi atau penggunaan energi alternatif, penghematan air, pengelolaan sampah, penggunaan pupuk organik. Diharapkan melalui program ini dikemudian hari warga sekolah tersebut dapat turut bertanggung jawab dalam upaya-upaya penyelamatan lingkungan dan pembangunan berkelanjutan.

Dari keunikan program Adiwiyata melalui pembelajaran lingkungan hidup yang dimiliki SD Al Muslim inilah sehingga perlu adanya informasi tentang Penerapan Program Adiwiyata di SD Al Muslim Wadung Asri Kecamatan Waru Kabupaten Sidoarjo, Kurikulum SD Al Muslim Wadung Asri Kecamatan Waru Kabupaten Sidoarjo, dan Faktor pendukung dan penghambat pembelajaran lingkungan hidup SD Al Muslim Wadung Asri Waru SidoarjoSekolah Dasar (SD) Al Muslim merupakan Sekolah yang sudah menerapkan Program Adiwiyata dengan memasukkan pembelajaran lingkungan hidup dalam kurikulumnya. Pembelajaran Lingkungan hidup yang diberikan kepada siswa SD Al Muslim ini merupakan bagian dari program Adiwiyata yang telah disahkan oleh Kementerian Negara Lingkungan Hidup (KLH) dengan Menteri Pendidikan Nasional (Depdiknas) tahun 1996 yang kemudian direvisi pada bulan Juni 2005. Penandatanganan MOU tersebut bermakna sebagai usaha untuk mengupayakan bagaimana kecintaan terhadap lingkungan sehingga dapat dijadikan sebagai muatan pendidikan bagi peserta didik sejak usia dini pada pendidikan formal. Karena segala yang tersusun atau terstruktur sejak awal, diharapkan dapat memberikan hasil atau pencapaian yang lebih baik dalam pengelolaan lingkungan hidup.

Program Adiwiyata bertujuan untuk menciptakan kondisi yang baik bagi sekolah untuk menjadi tempat pembelajaran dan penyadaran warga sekolah yang diwujudkan dalam bentuk: (1) Pengembangan kebijakan sekolah peduli dan berbudaya lingkungan, (2) Pengembangan kurikulum berbasis lingkungan, (3) Pengembangan kegiatan lingkungan berbasis partisipatif, dan (4) Pengembangan dan pengelolaan sarana pendukung sekolah berbudaya lingkungan seperti: hemat energi atau penggunaan energi alternatif, penghematan air, pengelolaan sampah, penggunaan pupuk organik. Diharapkan melalui program ini dikemudian 
hari warga sekolah tersebut dapat turut bertanggung jawab dalam upaya-upaya penyelamatan lingkungan dan pembangunan berkelanjutan.

\section{METODE PENELITIAN}

Penelitian ini dilakukan di Sekolah Dasar Al Muslim. Jl. Raya Wadungasri No.39 F, Waru, Sidoarjo. Penelitian ini dilakukan pada bulan Agustus - Oktober 2017. Subyek penelitian ini dilakukan dengan teknik "purposive sampling", yaitu orang yang paling banyak mengetahui tentang Program Adiwiyata yaitu tim adiwiyata sekolah yang terdiri dari: (1) kepala Sekolah (2) Guru 2 orang (3) Peserta didik 2 orang (4) wali murid 2 orang. Data dari informan akan dijadikan sebagai sumber primer sedangkan sumber data sekunder diperoleh melalui studi pustaka yaitu yang terkait dengan dokumen Program Adiwiyata.

Dalam penelitian ini yang menjadi instrumen penelitian sendiri, sebagaimana dikemukakan oleh Sugiyono (2005:59) menyatakan "dalam penelitian kualitatif yang menjadi instrumen atau alat penelitian adalah peneliti itu sendiri”. Dalam penelitian ini peneliti terjun langsung melakukan segala proses penelitian untuk melakukan pengumpulan data seperti menetapkan fokus penelitian, memilih informan sebagai sumber data.

Data penelitian ini data di analisis dengan metode yang dikemukakan oleh Miles dan Huberman yang dikutip oleh Sugiyono (2005:62) yaitu dengan reduksi data, dan penarikan kesimpulan. Prosedur pengumpulan data dengan menggunakan beberapa teknik dan alat pengumpulan data. Instrumen penelitian yang digunakan dalam penelitian yaitu: Forum Group Discussion (FGD), observasi, wawancara, dokumentasi, Catatan lapangan.

\section{HASIL DAN PEMBAHASAN}

Data yang diperoleh dalam penelitian ini merupakan data dalam bentuk narasi kalimat. Cakupan informasi yang ditelaah dari hasil wawancara didukung hasil observasi dan dokumentasi mengenai implementasi program Adiwiyata di SD Al Muslim Waru dapat diuraikan sebagai berikut:

\section{Penerapan Program Adiwiyata SD Al Muslim}

SD Al Muslim sebagai sekolah Adiwiyata telah memiliki dan mengembangkan kebijakan sekolah yang berwawasan lingkungan, diantara: a) Visi, Misi, dan Tujuan sekolah yang tertuang dalam kurikulum sekolah sudah memuat kebijakan perlindungan dan pengolahan lingkungan hidup. Visi, misi dan tujuan ini juga sudah terinternalisasi (tahu dan mengerti) oleh semua warga sekolah. Kebijakan ini berjalan dengan baik tanpa hambatan, b) srtuktur Jurnal Auladuna| 32

Vol. 미. №. Q2. पktober 2019 


\section{Budi Purwantiningsib}

Asnal Mala

kurikulum sekolah sudah memuat pada semua mata pelajaran wajib secara terintegrasi sedangkan pada muatan lokalnya sekolah memiliki muatan lokal Pendidikan Lingkungan Hidup (PLH) yang sifatnya monolitik (berdiri sendiri), telah memprogramkan kemampuan pendidik yang memiliki latar belakang pendidikan yang terkonsentrasi dengan lingkungan hidup maupun melalui diklat lingkungan hidup, telah melakukan sosialisasi terutama kepada warga sekolah yang dalam hal ini guru, pegawai tat usaha, dan siswa, para pendidik dan tenaga kependidikan mensosialisasi kepada siswa baik waktu di kelas maupun dalam kesempatan lain di lingkungan sekolah. Hal ini didukung dengan hasil observasi baik waktu upacara, rapat terbuka, dan proses pembelajaran di kelas, c) Pada muatan lokal Pendidikan Lingkungan Hidup (PLH) sudah dilengkapi dengan ketuntasan minimal belajar yaitu 75, d) Pertunjukan SK TIM penanggung jawab lingkungan hidup, e) Kebijakan sekolah mengikuti dan mengirimkan SDM (guru dan peserta didik) dalam seminar, workshop, pelatihan, penataran, pendidikan berjenjang dan studi banding, f) membuat SK larangan merokok di lingkungan sekolah, SK tata tertib pembuangan penghematan listrik, dan lain lain.

\section{2) Pelaksanaan Kurikulum Berbasis Lingkungan}

Pelaksanaan kurikulum yang berbasis lingkungan yang berbasis lingkungan yang sudah dilakukan oleh SD Al Muslim adalah: a) SD Al Muslim sudah menerapkan pendekatan, strategi, metode dan teknik pembelajaran yang melibatkan peserta aktif dalam pembelajaran. Metode yang digunakan seperti diskusi, penugasan, praktik langsung dan observasi, b) seudah mengembangkan isu lokl seperti banjir, polusi, dan atau isu lokal global seperti global sudah mengembangkan isu lokal seperti banjir, polusi dan atau isu global seperti global warming sebagai materi pembelajaran LH, c) Mengembangkan indikator dan instrumen penilaian pembelajaran LH hal ini terlihat pada program tahunan, program semester, silabus dan RPP yang dibuat, d) menyusun rancangan pembelajaran yang lengkap, baik untuk kegiatan didalam kelas, laboratorium, maupun diluar kelas, laboratorium, maupun diluar kelas yang terlihat dari RPP yang dibuat guru, e) adanya keikutsertaan orang tua peserta didik dan masyarakat dalam program pembelajaran LH baik secara langsung maupun tidak langsung. Keterlibatan ini terlibat dari keantusiasan orang tua peserta didik dan masyarakat. Keterlibatan ini terlihat dari keantusiasan orang tua peserta didik dan masyrakat dalam mendukung pembelajaran peserta didik dan keikutsertaan mereka dalam kegiatan sekolah yang berkaitan dengan lingkungan hidup, f) Tenaga pendidik mengkomunikasikan hasil-hasil inovasi pembelajaran LH seperti 
pada majalah dinding dan blog, g) mengkaitkan pengetahuan konseptual dan prosedural dalam pemecahan masalah LH, serta penerapannya dalam kehidupan sehari-hari, guru-guru memberikan contoh kepadanya siswanya untuk peduli terhadap lingkungan, h) Menghasilkan karya nyata yang berkaitan dengan pelestarian fungsi $\mathrm{LH}$, mencegah terjadinya pencemaran dan kerusakan LH.

\section{Kegiatan Rutin Sekolah}

\section{a) Kegiatan Harian}

Berdasarkan hasil penelitian, bentuk kegiatan rutin harian sekolah dalam melaksanakan pendidikan karakter peduli lingkungan adalah dengan kegiatan membuang sampah pada tempatnya disesuaikan dengan sifat sampahnya, untuk sampah organik biasanya dikelolah oleh siswa dengan bantuan guru pengampu pembelajaran lingkungan hidupnya. Yang kemudian hasil dari pengelolaan sampah tersebut bisa dimanfaatkan untuk tanaman di sekitar sekolah atau kadang dijual yang hasilnya akan digunakan kembali untuk biaya operasional lingkungan

Selain itu, siswa juga diberi kegiatan menanam tanaman obat dan tanaman sayuran di green house serta memelihara ikan secara bergiliran kelasnya sesuai dengan jadwal yang telah ditentukan oleh Sekolah.

\section{b) Kegiatan Bulanan dan Tahunan}

Kegiatan rutin bulanan adalah dengan memperingati hari-hari lingkungan seperti hari air dengan cara mengadakan meminum air putih secara yang dilakukan bersama-sama, memperingati hari pohon dengan cara menanam pohon di sekolah, memperingati hari gizi dengan cara membawa bekal dari rumah, membuat mading yang selalu dilakukan di sela-sela pembelajaran lingkungan hidup oleh Guru pengampunya, dan masih banyak lagi kegiatankegiatan lingkungan yang rutin bulanan dan tahunan yang dilakukan di SD AL Muslim Waru Sidoarjo.

I Adapun kegiatan yang bersifat tahunan adalah: Super Eco Camp yaitu kegiatan dengan mengadakan atau mengikuti lomba atau kegiatan pribadi yang di ikuti oleh SD Al Muslim. Contoh: melukis dengan pewarna alami, membatik dengan pewarna alami, mengikuti lombalomba di luar sekolah, membuat madding lingkungan, membuat slogan lingkungan, dan lain lain.

\section{Kegiatan Terprogram}

\section{a) Kegiatan Pengolahan Sampah}




\section{Budi Purwantiningsih}

Asnal Mala

Berdasarkan observasi dan wawancara kegiatan pengolahan sampah ini menekankan jadwal per kelas (piket halaman), jadi setiap kelas sudah dijadwal untuk membersihkan sampah, khususnya sampah daun. Kegiatan ini dilakukan untuk menangani sampah daun yaitu membersihkan sampah pada halaman/ tempat parkir motor dan juga hutan mini. Sampahsampah organik yang sudah dikumpulkan siswa akan ditampung dalam bank sampah yang kemudian sampah-sampah daun itu akan dijadikan kompos. Sedangkan untuk sampah anorganik yang berasal dari plastik dan botol air mineral akan dimanfaatkan kembali oleh siswa SD Al Muslim untuk dibuat kerajinan atau di jual dan hasilnya di manfaatkan untuk kebutuhan peduli lingkungan.

\section{b) Kegiatan Penghijauan}

Berdasarkan observasi dan wawancara yang dilakukan oleh Guru Pendamping SD Al Muslim, bahwa kegiatan penghijauan yang dilakukan di SD Al Muslim antara lain adalah setiap kelas yang memiliki jam pelajaran lingkungan hidup di ajak ke green house untuk menanam dan memelihara tanaman dan memelihara ikan lele. Kegiatan merawat tanaman di Green House SD Al Muslim dilakukan secara piket kelas setiap minggunya. Selain kegiatan di atas, siswa SD Al Muslim juga diberi kegiatan Green Skill, dimana siswa diajarkan mencangkok, pembibitan dan stek pada tumbuhan.

\section{Kegiatan Spontan}

Kegiatan spontan dilaksankan pada saat itu juga, tanpa adanya perenacanaan kegiatan pendidikan karakter Peduli lingkungan. Ketika ada siswa yang melakukan kegiatan peduli lingkungan maupun sebaliknya, secara spontan guru akan memberikan pendidikan karakter peduli lingkungan pada saat itu juga walaupun diluar kegiatan. Dalam pelaksanaan kegiatan pendidikan karakter peduli lingkungan melalui program Green Environment ini tidak hanya siswa siswi SD Al Muslim saja yang aktif berperan, akan tetapi guru dan kepala sekolah ikut berperan aktif dalam semua kegiatan

\section{Pengintegrasian Dalam Mata Pelajaran}

Berdasarkan hasil penelitian, Dengan dijadikannya SD Al Muslim Menjadi Sekolah Adiwiyata Mandiri maka upaya untuk menjadi lebih baik dari berbagai bidang terutama lingkungan hidupnya. Maka integrasi pendidikan LH dalam mata pelajaran di SD Al Muslim bersifat wajib sehingga SD AL Muslim membuat sebuah kurikulum yang menjadi Unggulan yaitu Kurikulum Green Environment yang dilaksanakan secara monolitik dan terintegrasi. Kurikulum ini nanti dijadikan pedoman dalam pelaksanaan kegiatan peduli lingkungan baik di Vol. 미. No. 02. Oktober 2019 
dalam Sekolah maupun di luar Sekolah. Selain itu kepala sekolah juga berperan memberikan evaluasi kepada kinerja guru dan siswa dalam pelaksanaan kegiatan apakah sudah baik atau belum.

Hasil di atas sesuai dengan Kementerian Pendidikan Nasional (2010:18) menjelaskan bahwa pengembangan nilai-nilai pendidikan budaya dan karakter bangsa dilakukan dalam pengintegrasian dalam mata pelajaran. Nilai-nilai peduli lingkungan dilaksanakan dan disampaikan dalam pengintegrasian dalam mata pelajaran. Memperlihatkan keterkaitan antara SK dan KD dengan nilai dan indokator untuk mentukan nilai pendidikan peduli lingkungan yang dikembangkan. Mencatumkan nilai-nilai yang berkaitan dengan peduli lingkungan pada silabus, rencana pelaksanaan pembelajaran (RPP).

Mengambangkan proses pembelajaran yang aktif, sehingga peserta didik dapat secara langsung mempraktikan nilai atau sikap peduli lingkungan. Memberikan bantuan kepada pserta didik dalam menginternalisasi nilai kepedulian terhadap lingkungan.

\section{Pengembangan Proses Pembelajaran}

\section{a. Kelas}

Hasil penelitian menyimpulkan bahwa pengembangan proses pembelajaran kelas yang dilakukan adalah dengan praktek langsung dan pengamatan langsung dalam proses pembelajaran. Kegiatan praktek dan pengamatan langsung dimaksudkan agar anak bisa langsung mengaplikasikan perilaku peduli lingkungan. Upaya pengembangan proses pembelajaran kelas yang dilaksanakan sesuai dengan Kementerian pendidikan nasional (2010:20) yang menyebutkan bahwa kelas, melalui proses belajar setiap mata pelajaran atau kegiatan yang dirancang sedemikian rupa. Setiap kegiatan belajar mengembangkan kemampuan dalam ranah kognitif, afektif, dan psikomotorik.

\section{b. Sekolah}

Kementerian pendidikan nasional (2010:21) Sekolah, melalui berbagai kegiatan sekolah yang diikuti seluruh peserta didik, guru, kepala sekolah, dan tenaga administrasi di sekolah itu, dirancang sekolah sejak awal tahun pelajaran, dan dimasukkan ke dalam Kalender Akademik dan yang dilakukan sehari-hari sebagai bagian dari budaya sekolah.

Pengembangan proses pembelajaran sekolah yang dilaksanakan Sekolah Dasar Al Muslim adalah dengan mengadakan pengarahan dan penyuluhan baik melalui pihak sekolah maupun dari pihak luar sekolah.

\section{c. Luar sekolah}

Jurnal Auladuna| 36

Vol. पl. No. 02. Uktober 2019 


\section{Budi Purwantiningsih}

Asnal Mala

Pengembangan proses pembelajaran di luar sekolah yang dilaksanakan Sekolah Dasar Negeri Al Muslim dalam pelaksanaan pendidikan karakter peduli lingkungan adalah dengan menambah jam kegiatan atau ekstrakurikuler, mengadakan kegiatan kunjungan keluar sekolah, dan melibatkan siswa dalam kegiatan di lingkungan sekolah.

Hal ini seuai dengan Kementerian pendidikan nasional (2010:22) yang menyebutkan bahwa pengembangan proses pembelajaran di luar sekolah, melalui kegiatan ekstrakurikuler dan kegiatan lain yang diikuti oleh seluruh atau sebagian peserta didik, dirancang sekolah sejak awal tahun pelajaran, dan dimasukkan ke dalam Kalender Akademik. Kegiatan di luar sekolah meliputi kegiatan ekstrakurikuler dan kegiatan di luar sekolah.

\section{Kesehatan Lingkungan Sekolah}

\section{a. Pemeliharaan ruang dan bangunan}

Berdasarkan hasil penelitian, pemeliharaan ruang dan bangungan sekolah dilakukan setiap hari dan melibatkan siswa. Hal ini sesuai dengan Keputusan Menteri Kesehatan Republik Indonesia Tahun 2006 tentang Pedoman Penyelenggaraan Kesehatan Lingkungan Sekolah, yang menyebutkan bahwa pemeliharaan ruang dan bangunan meliputi intensitas pelaksanaan kebersihan, kegiatan pembersihan, pengecatan dinding apabila telah usam. Kondisi ruang dan bangungan sekolah dalam kondisi dan keadaan baik.

\section{b. Ventilasi dan pencahayaan}

Keadaan ventilasi dan pencahayaan sudah sesuai dengan Keputusan Menteri Kesehatan Republik Indonesia Tahun 2006 tentang Pedoman Penyelenggaraan Kesehatan Lingkungan Sekolah. Kodisi pencahyaan di dalam kelas harus cukup dan merata, serta adanya pencahayaan tambahan jika ruangan dalam keadaan gelap. Ventilasi, ventilasi ruang untuk mendapatkan udara yang segar dan bersih.

\section{c. Fasilitas sanitasi}

Menteri Kesehatan Republik Indonesia Tahun 2006 tentang Pedoman Penyelenggaraan Kesehatan Lingkungan Sekolah. Fasilitas Sanitasi, sanitasi sekolah meliputi pengelolaan toilet, pengelolaan sarana pembuangan air limbah, pengelolaan saran pembuangan sampah. Berdasarkan pedoman penyelenggaraan kesehatan lingkungan sekolah tersebut sesuai dengan fasilitas sanitasi di Sekolah Dasar Negeri Al Muslim.

\section{d. Kantin sekolah}

Vol. ㄱ. No. 02. Uktober 2019

Jurnal Auladuna | 37 
Menurut Menteri Kesehatan Republik Indonesia Tahun 2006 tentang Pedoman Penyelenggaraan Kesehatan Lingkungan Sekolah. Kantin/warung sekolah hanya digunakan sebagai tempat makan bersama, adapun makanan sudah di siapkan dari pihak sekolah yang setiap hari berbeda menunya. Siswa wajib membawa perlengkapan makan dengan tujuan untuk menhidari banyaknya sampah. Sehingga SD Al muslim selalu mengutamakan kebersihan dan kesehatan dari makanan yang dijual untuk dikonsumsi oleh siswa.

Adapun kue yang dimakan peserta didik ketika siang merupakan tugas dari wali murid sehingga diharapkan dapat berlaku kooperatif untuk menjaga kesehatan makanan yang dimakan.

\section{e. Bebas dari jentik nyamuk}

Sekolah melibatkan siswa dalam mekakukan pencegahan tumbuhnya nyamuk dengan mengajak siswa membersihkan bak mandi. hal ini sesuai dengan keputusan Menteri Kesehatan Republik Indonesia Tahun 2006 tentang Pedoman Penyelenggaraan Kesehatan yang menyebutkan bahwa lingkungan sekolah harus bebas dari jentik nyamuk.

Berdasarkan hasil penelitian menunjukkan bahwa lingkungan sekolah terbebas dari jentik nyamuk..

\section{f. Bebas asap rokok}

Keputusan Menteri Kesehatan Republik Indonesia Tahun 2006 tentang Pedoman Penyelenggaraan Kesehatan Lingkungan Sekolah Bebas Asap Rokok, terdapat larangan dan himbauan untuk tidak merokok di lingkungan sekolah.

Berdasarkan hasil penelitian yang dilakukan, himbauan dan larangan merokok di lingkungan sekolah sudah tercantum dalam tata tertib sekolah. Kepala sekolah dan guru melakukan himbauan dan larangan langsung kepada warga sekolah untuk tidak merokok di lingkungan sekolah.

\section{g. Promosi hygiene dan sanitasi sekolah}

Berdasarkan hasil penelitian, bahwa dalam melakukan promosi hygiene dan sanitasi sekolah, sekolah menyediakan fasilitas yang menunjang promosi bygiene dan sanitasi sekolah. Sekolah melakukan himbauan dan ajkan kepada warga sekolah secara langsung maupun lewat kegiatan upacara.

\section{Hambatan dalam Pelaksanaan Program Adiwiyata di SD Al Muslim Waru Sidoarjo}

\section{a) Kondisi Siswa}

Jurnal Auladuna| 30

Vol. ㅁ. No. 02. Oktober 2019 


\section{Budi Purwantiningsih}

Asnal Mala

Berdasarkan observasi yang dilakukan pada tanggal 24 Mei 2013, ketika berlangsungnya kegiatan jum'at bersih, ada beberapa siswa yang tidak mau melaksanakan tugas mereka untuk membersihkan lingkungan SD Al Muslim sesuai dengan pembagian tugas bahkan mengeluh. Mereka enggan melakukan kegiatan tersebut dikarenakan tidak bisa, atau karena tidak terbiasa melakukan hal itu, ada yang merasa jiijk pula.

\section{b) Waktu}

Waktu merupakan salah satu faktor penghambat pelaksanaan program Adiwiyata, hal ini disebabkan karena pengenalan lingkungan lebih banyak memerlukan waktu dibanding dengan proses belajar mengajar reguler. Karena selain siswa mendapatkan teori tentang lingkungan hidup, mereka juga mendapatkan praktik lapangan. Bisa di lakukan di dalam kelas atau kadang bisa dilakukan di luar kelas seperti di Green house atau di halaman sekolah yang berfungsi sebagai media pembelajaran.

\section{c) Tenaga Pendidik}

Tenaga pendidik atau guru baru yang mulai mengajar di Al Muslim juga merupakan salah satu faktor penghambat karena belum mengenal program Adiwiyata, sehingga perlu pembinaan dahulu sebelum mereka mengajar

\section{d) Keterbatasan Lahan}

Lahan yang digunakan untuk melakukan kegiatan Green Environment yang bertempat di samping sekolah yaitu green house relatif lebih kecil bila dibandingkan dengan rasio jumlah siswa SD Al Muslim yang banyak. Sehingga perlu adanya solusi untuk mengatasi hal tersebut. Kemudian jumlah tanaman hendaknya lebih bervariatif misalnya pohon yang dikotil karena bisa tumbuh dewasa dan lebh banyak manfaatnya.

\section{SIMPULAN DAN SARAN}

\section{a. Kesimpulan}

1. Penerapan Pembelajaran Lingkungan Hidup melalui program Adiwiyata terdiri atas kegiatan Penghijauan dan pengolahan sampah. Strategi yang digunakan dalam program ini adalah pembiasaan dengan transformasi budaya sekolah melalui kegiatan rutin, kegiatan terprogram dan kegiatan spontan. Dalam pelaksanaan pendidikan karakter Peduli lingkungan SD Al Muslim melibatkan beberapa pihak baik keluarga masyarakat maupun pihak lain yang terkait. Pembelajaran lingkungan hidup diberikan melalui kegiatan-kegiatan yang menumbuhkan tindakan berupa pembiasaan dan pemberian teori dengan memberikan pengetahuan mengenai lingkungan.

Vol. ㄱ. No. Q2. Oktober 2019 
2. Kurikulum SD Al Muslim untuk mendukung Program Adiwiyata adalah Pembelajaran Green Environment secara monolitik dan terintegrasi. Pendekatan monolitik merupakan pendekatan lingkungan hidup merupakan satu mata pelajaran yang berdiri sendiri dan terpisah tanpa di sisipkan ke dalam mata pelajaran lainnya. Sedangkan pendekatan terintegrasi adalah penerapan mata pelajaran lingkungan hidup yang disisipkan pada mata pelajaran yang lainnya. Kurikulum Adiwiyata di SD Al Muslim ini merupakan kurikulum unggulan yang sudah dipersiapkan terlebih dahulu baik perangkat pembelajarannya maupun teori yang akan disampaikan kepada siswa SD Al muslim Waru Sidoarjo. Sedangkan pelaksanaan pemberian materi pembelajaran lingkungan hidup 2 × 35 menit perminggu. Sedangkan materi yang diberikan meliputi 6 pilar Green Environment (GE). Adapun yang menyusun materi dalam program adiwiyata ini adalah Guru pengampu pelajaran lingkungan hidup (Tim GE). Metode yang digunakan adalah CTL, Kooperatif dan PBL (Problem Base Learning). Selain itu pihak sekolah bekerja sama dengan pihak luar misalnya LSM, Masyarakat sekitar dan Sekolah sekitar

3. Faktor penghambat yang ditemukan dalam penerapan pembelajaran lingkungan hidup melalui Program Adiwiyata terdiri dari: hambatan dari dalam dan hambatan dari luar. Hambatan dari dalam atau intern terdiri atas:1) kondisi siswa yang terkadang masih ada yang susah diatur dalam pelaksanaan kegiatan, 2) keterbatasan waktu pembelajaran GE, 3) Tenaga pendidik baru karena belum mengenal Program Adiwiyata, 4) Keterbatasan Lahan hijau. Sedangkan untuk hambatan dari luar atau ekstern terdiri atas:1) keluarga atau orang tua siswa yang masih ada saja sebagian kecil dari mereka tidak ikut secara aktif memberikan pendidikan karakter peduli lingkungan kepada siswa dengan cara tidak memperbolehkan ikut kegiatan dengan alasan tertentu. 2) Masyarakat, di sekitar Sekolah masih banyak yang tidak sadar lingkungan misalnya membuang sampah sembarangan, padahal sudah disiapkan TPA. Adapun solusi untuk mengatasi hambatan yang dialami dalam pelaksanaan kegiatan pembelajaran lingkungan hidup melalui Program Adiwiyata di SD Al Muslim antara lain adalah: 1) Pemberian contoh oleh tenaga pendidik, 2) Mensiasati Waktu, 3) memperluas Lahan hijau, 4) Pemberian pengarahan bagi keluarga dan masyarakat.

\section{B. Saran}

1. Sekolah SD Al Muslim ini sudah menjadi Sekolah Adiwiyata Mandiri sehingga SD Al Muslim harus tetap mempertahankan Pembelajaran Lingkungan hidup melalui Program 


\section{Budi Purwantiningsih}

Asnal Mala

Adiwiyata sebagai sarana mendidik karakter peduli lingkungan bagi anak-anak penerus bangsa.

2. Dalam kegiatan peduli lingkungan lebih memperbanyak melakukan kegiatan di luar lingkungan SD Al Muslim dengan lebih melibatkan masyarakat, sehingga Pendidikan karakter Peduli lingkungan tidak hanya diajarkan kepada siswa siswi SD Al Muslim saja tetapi juga masyarakat.

\section{DAFTAR PUSTAKA}

Abdurrahman. 2004. Pengantar Hukum Lingkungan Indonesia. Bandung: Alumni

Arikunto, Suharsimi. 2006. Prosedur Penelitian Suatu Pendekatan Praktek. Jakarta: Rieneke Cipta

Asmani, Jamal Ma'ruf. 2012. Buku Panduan Internalisasi pendidikan Karakter di Sekolah. Jogjakarta: DIVA Press

Ben Senang Galus, 2010. Pendidikan Lingkungan Hidup: Untuk Sebuah Keberlanjutan Hidup Bersama. Jurnal dikpora

Hamzah, Syukri. 2013. Pendidikan Lingkungan: Sekelumit Wawasan Pengantar.Bandung: Refika Aditama.

Megawangi, Ratna. 2004. Pendidikan Karakter "Solusi yang Tepat Membangun Bangsa". Jakarta: BM.MIGAS

Miles, Mattew B, Huberman Michael A. 2007. Analisis data kualitatif:Buku Sumber tentang Metodemetode Baru. Jakarta: Universitas Indonesia.

Moeleong, Lexy J. 2011. Metodologi Penelitian Kualitatif. Bandung. Remaja Rosda Karya

Muslich, Masnur.2011. Pendidikan Karakter Menjawab Tantangan Krisis Dimensional. Jakarta: Bumi Aksara

Mustakim, Bagus. 2011. Pendidikan Karakter Membangun Delapan Karakter Emas Menuju Indonesia Bermartabat. Yogyakarta: Samudra Biru

Nirarita ECh. 2003. Pendidikan Lingkungan Hidup dalam Sekolah Formal. Di dalam: Muntasib EKSH, Meilani R, editor. Model Pengembangan Pendidikan tentang Hutan dan Lingkungan Bagi Anak Sekolah.

Nurla, Isna Aunillah. 2011. Panduan Menerapkan Pendidikan Karakter di Sekolah. Jakarta: Laksana

Prosiding Workshop Model Pengembangan Pendidikan tentang Hutan dan Lingkungan bagi Anak Sekolah. Bogor: 24 Apr 2003. Bogor: Fakultas Kehutanan Institut Pertanian Bogor, Pusat Bina Penyuluhan Kehutanan Departemen Kehutanan, dan The Nature Conservancy.

Pusat Bahasa Departemen Pendidikan Nasional. 2008. Kamus Bahasa Indonesia. Jakarta: Pusat Bahasa. Cet. I.

Ryan, Kevin \& Bohlin, K. E. 1999. Building Character in Schools: Practical Ways to Bring Moral Instruction to Life. San Francisco: Jossey Bass.

Sugiyono. 2013. Metode Penelitian Pendidikan (Pendekatan Kuantitatif, Kualitatif, dan RND). Bandung : Alfabeta.

Undang-undang Republik Indonesia Nomor 32 Tahun 2009 tentang Perlindungan dan Pengelolaan Lingkungan Hidup

Undang-undang Republik Indonesia Nomor 10 Tahun 2003 tentang Sistem Pendidikan Nasional

Vol. ㄱ. No. 02. Uktober 2019

Jurnal Auladuna | $4 \mid$ 